\title{
Responsiveness of spring barley cultivars to top-dressing in the conditions of the Volga- Vyatka region
}

\author{
E.N. Noskova*, I.N. Shchennikova, and E.V. Svetlakova \\ Federal Agricultural Research Center of the North-East named N.V. Rudnitsky, 610007 Kirov, Rus- \\ sian Federation
}

\begin{abstract}
Fertilizers are a means of influencing both the value of the yield and its quality. The quality of the yield will vary depending on the types of fertilizer, the timing and methods of their application, and the balance of ratios for the main nutrition elements. Under the conditions of field experiments on sod-podzolic soil, the influence of various types of top-dressing on the yield and quality traits of barley grains of the cv. Novichok, Rodnik Prikamya and Pamyati Rodinoj was studied. High efficiency of application of all top-dressings on grain yield capacity of barley cv. Novichok has been established. The use of liquid mineral fertilizer KAS in the tillering stage contributed to an increase in the yield of barley cv. Rodnik Prikamya and Pamyati Rodinoj by 0.34 and $0.31 \mathrm{t} / \mathrm{ha}$. The barley cv. Pamyati Rodinoj also responded positively to the input of the preparation Alfastim in the heading stage; the grain yield increase was $0.82 \mathrm{t} / \mathrm{ha}$. The high efficiency of top-dressings on the physical properties of grains has been established in barley cv. Novichok and Pamyati Rodinoj. The protein content in the cv. Pamyati Rodinoj was increased during treatment of sowings with preparation Amino Start in the tillering stage by $15.0-16.5 \mathrm{~g} / \mathrm{kg}$. In the cv. Novichok, when inputting the growth stimulant Alfastim at heading stage, an increase in protein content by $4.0-4.8 \mathrm{~g} / \mathrm{kg}$ was noted. In terms of fiber content, the obtained grains of all cultivars meet the requirements of the first class grain.
\end{abstract}

\section{Introduction}

Barley is a unique culture, both in biological features and in economic-and-useful features. Its main advantages are drought resistance, high productivity, good feed quality and the possibility of universal use. In the Kirov region, the main sowing areas of barley are used to produce grain fodder and in mixed feed industry, since the grain of this crop is distinguished by a better balance of protein, including the main essential amino acids.

An urgent solution to the problem of increasing grain productivity and quality could be the expansion of sown areas for new high-yielding domestic barley cultivars and the development of technologies for their cultivation for fodder purposes. These cultivars are charac-

*Corresponding author: zemledel_niish@mail.ru 
terized by high adaptation to growing conditions: drought, soil acidity, and diseases. In terms of yield capacity and grain quality, they are not inferior to cultivars of foreign breeding, but in unfavorable conditions exceed them [1,2].

However, gross yields and yield capacity of spring barley are subject to sharp fluctuations every year. The main reasons for this are unfavorable weather conditions, violation of cultivation technologies $[3,4]$, reduction of quantities of inputted fertilizers [5-7] and deterioration of phytosanitary state of sowings [8]. One way to increase resistance to negative environmental factors is the use of top-dressings of barley sowings [9]. Fertilizers are means of influencing both the value of the yield and its quality. The yield quality will depend on the type of fertilizer, the timing and the manner in which it is applied, and the balance between the ratios of the main nutrients. With a rational fertilizer system, the consumption of nutritional elements for the formation of a unit of production will be lower and the nutritional elements will be spent more economically.

The yield level of individual cultivars in industrial conditions is determined by their biological properties and the reaction to growing conditions. The purpose of our research was to study the reaction of spring barley cultivars bred in Federal Agricultural Research Center of the North-East (FARC) to the use of top-dressed fertilizers and the identification of the most responsive cultivars. Therefore, the study of the influence of spring barley topdressing on the change in grain yield capacity and grain quality in the conditions of the Kirov region is an urgent area of research.

\section{Materials and methods}

Field experiments were carried out in 2020 at the FARC of the North-East. The subjects of research were spring barley cv. Novichok, Rodnik Prikamya and Pamyati Rodinoj. NPKS mineral fertilizers $(25: 4: 4: 2)$ at a dose of $0.3 \mathrm{t} /$ ha were applied under pre-sowing cultivation.

The plot area is $10 \mathrm{~m}^{2}$, the repetition of the experiment is four times.

As an organic-mineral fertilizer, Polydon Amino Start and Alphastime fertilizers were used, which include macro-, meso- and micronutrients in combination with amino acids and low-molecular peptides for the initial stages of vegetation, and leaf treatment with Alfastim in the second half of vegetation is recommended to increase the yield amount and quality.

Organic-mineral fertilizer Amino Start includes: L-amino acids $(200 \mathrm{~g} / \mathrm{l})$, nitrogen $(\mathrm{N}$ total - $130 \mathrm{~g} / \mathrm{l})$, phosphorus (P2O5 - $75 \mathrm{~g} / \mathrm{l})$, potassium $(\mathrm{K} 2 \mathrm{O}-25 \mathrm{~g} / \mathrm{l})$, magnesium $(\mathrm{MgO}-$ $15 \mathrm{~g} / \mathrm{l})$, Iron (Fe - $6 \mathrm{~g} / \mathrm{l})$, manganese (Mn - $3 \mathrm{~g} / \mathrm{l})$, zinc $(\mathrm{Zn}-3 \mathrm{~g} / \mathrm{l})$, copper $(\mathrm{Cu}-3 \mathrm{~g} / \mathrm{l})$, boron (B - $3 \mathrm{~g} / \mathrm{l})$, molybdenum (Mo $-1 \mathrm{~g} / \mathrm{l})$, and cobalt $(\mathrm{Co}-0.05 \mathrm{~g} / \mathrm{l})$. It is used to stimulate the growth of the root system, increase number of ear-bearing stems, increase plant stress resistance and yield.

The composition of the growth stimulator Alfastim includes: triterpenic acids $(100 \mathrm{~g} / \mathrm{l})$, L-amino acids (50 g/l), carbohydrates (50 g/l), auxin-cytokinin complex (10 g/l), membrane active substances $(10 \mathrm{~g} / \mathrm{l})$, vitamins (B1, B7, PP - $5 \mathrm{~g} / \mathrm{l})$. Preparation is designed to activate the most important metabolic reactions; regulates the absorption and use of nutrient elements; stimulates the root exudation and increases the permeability of the root cell walls. It has an immune-stimulating effect. It has the properties of an antioxidant and adaptogen. It increases resistance to water shortage, salt and chemical stresses, the effects of attacks by pathogens and pests.

Experiment design:

1 - without top-dressing (control);

2 - top-dressing with CAS (30 1/ha) at the tillering stage;

3 -top-dressing with Polydon Amino Start (1 1/ha) at the tillering stage; 
4 - top-dressing with Alfastim ( $50 \mathrm{ml} / \mathrm{ha}$ ) at the heading stage.

Harvesting was carried out by the Wintersteiger harvester in the stage of full wax ripeness.

Yield data are given to $14 \%$ humidity and $100 \%$ purity. Mass of 1000 grains was determined according to GOST 10842-89, volume weight (weight of 1 liter of grain) - GOST 10840-2017. Analysis of the physic-chemical properties of barley grains was performed on an INFRAMATIC device manufactured by Perten Instruments (Sweden).

The 1000-grain mass indicates the grain size. The larger the grain, the greater the 1000grain mass. This trait also characterizes the grain density. With an equal size, a large 1000grain mass indicates a larger reserve of nutrients in the grain. To determine the 1000-grain mass, two portion of grain were taken. The analysis is carried out for each portion separately. The portion, after thoroughly mixing, is distributed in an even layer in the form of a square. The square is divided by two diagonals into four sectors (triangles). From each triangle, 250 barley seeds are counted in a row without choosing. Grains counted from two opposite triangles are combined. Two parties of 500 grains are obtained. The 1000-grain mass is obtained by combining weight of two 500-grain parties. Volume weight is determined on a 1-liter magenta PKh-1 with a falling load. Before determining volume weight on a liter magenta, the average sample is released from large impurities, sieving it on a screen with 6-mm holes. The higher is volume weight, i.e. the bulk mass of the grain, the more useful substances it contains. High-volume weight grain is well developed; it contains relatively more endosperm than seed coats.

Weather conditions are an important factor in the formation of the quantity and quality of barley grains. It was established that the yield is negatively affected by high air temperatures during the sowing-tillering and heading-waxy ripeness periods; and excess moisture in the arable layer of the soil - during the grain ripening [10].

During the sowing and formation of barley seedlings in May, it was noted high amount of precipitations - about $165 \%$ of the perennial standard. The sum of active temperatures at the end of May was $227^{\circ} \mathrm{C}$. All this contributed to the early and good sprouts. By the time the barley was harvested in August 2020, the sum of active temperatures was $1328{ }^{\circ} \mathrm{C}$. Thus, the current weather conditions of the growing season were generally favorable for the cultivation of spring barley and made it possible to obtain a grain yield of 2.95-5.99 t/ha.

\section{Results and discussion}

Counting the yield of the studied cultivars showed that the highest grain yield was obtained in the cv. Pamyati Rodinoj (5.40 t/ha on average for all variants); it was lowest in the cv. Novichok and averaged on the variants of $3.74 \mathrm{t} / \mathrm{ha}\left(\mathrm{LSD}_{05} \mathrm{~A}=0.54\right)(\mathrm{tab} .1)$.

Table 1. Influence of top-dressings on yield capacity of spring barley, $t / \mathrm{ha}$.

\begin{tabular}{|c|c|c|c|c|c|}
\hline \multirow[b]{2}{*}{$\begin{array}{l}\text { Cultivar } \\
\text { (factor A) }\end{array}$} & \multicolumn{4}{|c|}{ Mineral nutrition (factor B) } & \multirow[b]{2}{*}{$\begin{array}{l}\text { Average on } \\
\text { factor A }\end{array}$} \\
\hline & $\begin{array}{l}\text { Control } \\
\text { (without top- } \\
\text { dressing) }\end{array}$ & $\begin{array}{l}\text { top-dressing } \\
\text { with CAS at } \\
\text { the tillering } \\
\text { stage }\end{array}$ & $\begin{array}{l}\text { top-dressing } \\
\text { with Polydon } \\
\text { Amino Start } \\
\text { at the tiller- } \\
\text { ing stage }\end{array}$ & $\begin{array}{c}\text { top-dressing } \\
\text { with Alfastim at } \\
\text { the heading } \\
\text { stage }\end{array}$ & \\
\hline Novichok & 2.95 & 3.38 & 4.22 & 4.39 & 3.74 \\
\hline Rodnik Prikamya & 5.03 & 5.37 & 5.01 & 4.86 & 5.07 \\
\hline Pamyati Rodinoj & 5.17 & 5.48 & 5.99 & 4.94 & 5.40 \\
\hline $\begin{array}{l}\text { Average on factor } \\
\text { B }\end{array}$ & 4.39 & 4.74 & 5.07 & 4.73 & \\
\hline $\mathrm{LSD}_{05}$ & & $\mathrm{~A}=0.5$ & $\mathrm{~B}=0.25$ & $\mathrm{AB}=0.65$ & \\
\hline
\end{tabular}


Top-dressing nutrition, on average in cultivars, had a positive effect on barley yield. However, the studied cultivars reacted to them differently. So, the cv. Novichok turned out to be the most responsive to improving the nutritional regime and responded positively to all top-dressings and gave a yield increase of $0.43-1.44 \mathrm{t} / \mathrm{ha}$. In the cv. Rodnik Prikamya and Pamyati Rodinoj, a reliable increase in yield was noted when using CAS in the tillering stage ( 0.34 and $0.31 \mathrm{t} / \mathrm{ha}$, respectively). It should be noted that the cv. Pamyati Rodinoj also gives a reliable increase in yield when carrying out top-dressing with the preparation Amino Start $-0.82 \mathrm{t} / \mathrm{ha}\left(\mathrm{LSD}_{05}=0.25\right)$. The application of preparation Alfastim at heading stage was ineffective. The cv. Rodnik Prikamya turned out to be less responsive to application of the studied preparations. Similar results were obtained in [11].

The physical properties of grain are closely related to yield capacity and are a cultivar feature. The volume weight of grain depended on the cultivar features of spring barley and the feed used. With statistical processing, it was established that the part of influence of the factor "cultivar" on the formation of this feature was $70.0 \%$. The volume weight of spring barley cv. Novichok averaged 677.2 g/l (tab. 2), cv. Rodnik Prikamya - 689.1 g/l, cv. Pamyati Rodinoj - $673.8 \mathrm{~g} / \mathrm{l}$. On average in cultivars, the increase in grain volume weight was influenced by the application of preparation Alfastim at heading stage; it increased by 4.9 $\mathrm{g} / 1\left(\mathrm{LSD}_{05}=2.7\right)$.

Table 2. Influence of top-dressings on grain volume weight of spring barley, g/l.

\begin{tabular}{|l|c|c|c|c|c|}
\hline \multirow{2}{*}{$\begin{array}{c}\text { Cultivar } \\
\text { (factor A) }\end{array}$} & $\begin{array}{c}\text { Control } \\
\text { (without top- } \\
\text { dressing) }\end{array}$ & $\begin{array}{c}\text { top-dressing } \\
\text { with CAS at } \\
\text { the tillering } \\
\text { stage }\end{array}$ & $\begin{array}{c}\text { top-dressing } \\
\text { with Polydon } \\
\text { Amino Start at } \\
\text { the tillering } \\
\text { stage }\end{array}$ & $\begin{array}{c}\text { top-dressing } \\
\text { with Alfastim at } \\
\text { the heading } \\
\text { stage }\end{array}$ & $\begin{array}{c}\text { Average on } \\
\text { factor A }\end{array}$ \\
\hline Novichok & 671.8 & 676.2 & 679.5 & 681.5 & 677.2 \\
\hline $\begin{array}{l}\text { Rodnik } \\
\text { Prikamya }\end{array}$ & 690.8 & 688.5 & 687.5 & 689.5 & 689.1 \\
\hline $\begin{array}{l}\text { Pamyati } \\
\text { Rodinoj }\end{array}$ & 671.8 & 676.0 & 669.2 & 678.0 & 673.8 \\
\hline $\begin{array}{l}\text { Average } \\
\text { on factor } \\
\text { B }\end{array}$ & 678.1 & 680.2 & 678.8 & 683.0 & \\
\hline LSD $_{05}$ & \multicolumn{7}{|c|}{$\mathrm{A}=6.2$} & $\mathrm{~B}=2.7$ & $\mathrm{AB}=7.4$ \\
\hline
\end{tabular}

The studied cultivars responded differently to the top-dressing application. So, the cv. Novichok gave a significant increase in volume weight for all studied preparations by 4.4 $9.7 \mathrm{~g} / \mathrm{l}$ ha $\left(\mathrm{LSD}_{05}=2.7\right)$. Cv. Rodnik Prikamya was the most stable in this indicator. The treatment of this cultivar with CAS in the tillering stage and with Alfastim in the heading stage had no significant effectiveness. The use of the preparation Amino Start allowed to increase the volume weight of barley grains by $3.3 \mathrm{~g} / 1$ compared to the control. The $\mathrm{cv}$. Pamyati Rodinoj also responded positively to the use of CAS in the tillering stage and Alfastim in the heading stage, the volume weight indicator increased by 4.2 and $6.2 \mathrm{~g} / 1 \mathrm{re}-$ spectively.

The yield capacity and grain quality largely depends on the 1000-grain mass, expressed in grams. Based on the results of the studies, a close positive correlation between yield capacity and 1000-grain mass was established $(r=0.92)$.

The 1000-grain mass can vary widely within one cultivar depending on the growing conditions. The determining factors in the formation of this indicator are the supplying of plants with water and nutrients. Studies have shown that the weight of barley grains is more determined by the cultivar (influence of the cultivar is $87.4 \%$ ). Among the studied cultivars, the largest 1000-grain mass was in the cv. Pamyati Rodinoj - 50.31-51.70 g (tab. 3). Smaller grain was characterized by the cv. Novichok $-43.12-45.70 \mathrm{~g}$. The 1000 -grain mass of 
barley cv. Rodnik Prikamya was 48.10-49.68 g. Top-dressing with organic-mineral fertilizer Amino Start and growth stimulant Alfastim made it possible to increase the 1000-grain mass by 0.87 and $0.63 \mathrm{~g}$ relative to control. The cv. Novichok responded best to application of top-dressing preparations; the increase was from $1.23 \mathrm{~g}$ when treating with CAS in the tillering stage to $2.58 \mathrm{~g}$ when applying the Alfastim in the barley heading stage $\left(\mathrm{LSD}_{05} \mathrm{~B}=\right.$ 0.34). In the cv. Rodnik Prikamya, the application of liquid mineral fertilizer CAS, organicmineral fertilizer Amino Start, and growth stimulator Alfastim was not effective. Barley cv. Pamyati Rodinoj positively responded to the application of Amino Start and Alfastim; an increase in the 1000-grain mass by $0.88-1.79 \mathrm{~g}$ was noted. In the studies [12], the use of bio-preparations also contributed to an increase in the 1000-grain mass of spring barley by 2.0-6.3 g compared to the variant where they were not used.

Table 3. Influence of top-dressings on 1000-grain mass, g.

\begin{tabular}{|c|c|c|c|c|c|}
\hline \multirow[b]{2}{*}{$\begin{array}{l}\text { Cultivar } \\
\text { (factor A) }\end{array}$} & \multicolumn{4}{|c|}{ Mineral nutrition (factor B) } & \multirow[b]{2}{*}{$\begin{array}{c}\text { Average on } \\
\text { factor A }\end{array}$} \\
\hline & $\begin{array}{c}\text { Control } \\
\text { (without top- } \\
\text { dressing) }\end{array}$ & $\begin{array}{c}\text { top-dressing } \\
\text { with CAS at } \\
\text { the tillering } \\
\text { stage }\end{array}$ & $\begin{array}{l}\text { top-dressing } \\
\text { with Polydon } \\
\text { Amino Start } \\
\text { at the tiller- } \\
\text { ing stage }\end{array}$ & $\begin{array}{l}\text { top-dressing } \\
\text { with Alfastim at } \\
\text { the heading } \\
\text { stage }\end{array}$ & \\
\hline Novichok & 43.12 & 44.35 & 45.23 & 45.70 & 44.60 \\
\hline Rodnik Prikamya & 49.68 & 49.57 & 48.91 & 48.10 & 49.06 \\
\hline Pamyati Rodinoj & 50.82 & 50.31 & 52.10 & 51.70 & 51.23 \\
\hline Average on factor $\mathrm{B}$ & 47.87 & 48.08 & 48.74 & 48.50 & \\
\hline $\mathrm{LSD}_{05}$ & \multicolumn{4}{|c|}{$\mathrm{A}=0.53$} & \\
\hline
\end{tabular}

According to GOST R53900-2010, barley grains for forage use are divided into three quality classes for the content of raw protein and raw fiber. Class 1 forage grain should contain more than $130 \mathrm{~g} / \mathrm{kg}$ of raw protein and less than $70 \mathrm{~g} / \mathrm{kg}$ of raw fiber; Class 2 $120-130 \mathrm{~g} / \mathrm{kg}$ of crude protein and $70-90 \mathrm{~g} / \mathrm{kg}$ of fiber; Class 3 - less than $120 \mathrm{~g} / \mathrm{kg}$ of raw protein and more than $90 \mathrm{~g} / \mathrm{kg}$ of raw fiber.

Increasing the productivity of spring barley cultivars, it is important to maintain the grain quality, one of which is the grain protein content. There were no significant differences in grain protein content on average for cultivars (tab. 4). This indicator was highest in the cv. Pamyati Rodinoj - 114.6 to $131.1 \mathrm{~g} / \mathrm{kg}$ of grain, depending on the experiment variant. In the cv. Novichok and Rodnik Prikamya, on average in the variants, the protein content was 109.9 and $114.0 \mathrm{~g} / \mathrm{kg}$ of grain, respectively.

The studies established an average positive correlation between the protein content in the grain and the 1000-grain mass $(r=0.68)$. At the same time, cultivar differences were noted in the effect of top-dressings on the protein content of the grain. So, in the cv. Novichok, a reliable increase in the content of raw protein was noted when processing with Alfastim in the heading stage by $4.0-4.8 \mathrm{~g} / \mathrm{kg}$ of grain, in the cv. Pamyati Rodinoj, the use of Amino Start in the tillering stage increased grain protein content by $15.0-16.5 \mathrm{~g} / \mathrm{kg}$. The influence of top-dressings on the protein content in the grain of the cv. Rodnik Prikamya has not been revealed.

Table 4. Influence of top-dressings on protein content in barley grain, $\mathrm{g} / \mathrm{kg}$.

\begin{tabular}{|l|c|c|c|c|c|}
\hline \multirow{2}{*}{$\begin{array}{c}\text { Cultivar } \\
\text { (factor A) }\end{array}$} & $\begin{array}{c}\text { Control } \\
\text { (without top- } \\
\text { dressing) }\end{array}$ & $\begin{array}{c}\text { top-dressing } \\
\text { with CAS at } \\
\text { the tillering } \\
\text { stage }\end{array}$ & $\begin{array}{c}\text { top-dressing } \\
\text { with Polydon } \\
\text { Amino Start } \\
\text { at the tiller- } \\
\text { ing stage }\end{array}$ & $\begin{array}{c}\text { top-dressing } \\
\text { with Alfastim at } \\
\text { the heading } \\
\text { stage }\end{array}$ & $\begin{array}{c}\text { Average on } \\
\text { factor A }\end{array}$ \\
\hline Novichok & 109.2 & 108.7 & 108.4 & 113.2 & 109.9 \\
\hline Rodnik Prikamya & 119.5 & 119.3 & 110.3 & 106.7 & 114.0 \\
\hline Pamyati Rodinoj & 114.6 & 116.1 & 131.1 & 114.6 & 119.1 \\
\hline
\end{tabular}




\begin{tabular}{|l|c|c|c|c|c|}
\hline Average on factor B & 114.4 & 114.7 & 116.6 & 111.5 & \\
\hline $\mathrm{LSD}_{05}$ & \multicolumn{4}{|c|}{$\mathrm{A}=\mathrm{F}_{\phi}<\mathrm{F}_{\mathrm{T}} \quad \mathrm{B}=2.0$} & $\mathrm{AB}=8.3$ \\
\hline
\end{tabular}

Correlation analysis showed that with an increase in the 1000-grain mass, the fiber content of the grain decreased $(r=-0.75)$. Raw fiber is a coarse and difficult-to-digest component of plants. The more it is in feed for farm animals, the lower its fodder dignity. At the same time, all animals need fiber in moderate amounts to stimulate the intestinal tract [13]. The obtained grain of all cultivars belongs to the first class; the fiber content did not exceed $70 \mathrm{~g} / \mathrm{kg}$ of raw fiber and varied in the range of $28.1-39.5 \mathrm{~g} / \mathrm{kg}$ (tab. 5). The studied top-dressings did not significantly affect this indicator. However, there was a significant difference in grain fiber content in the cultivars. In the cv. Pamyati Rodinoj and Rodnik Prikamya, the fiber content on average in the variants was 30.6 and $30.7 \mathrm{~g} / \mathrm{kg}$ of grain, which is 5.4 and $5.3 \mathrm{~g} / \mathrm{kg}$ lower than in the cv. Novichok.

Table 5. Influence of top-dressings on fiber content in barley grain, $\mathrm{g} / \mathrm{kg}$.

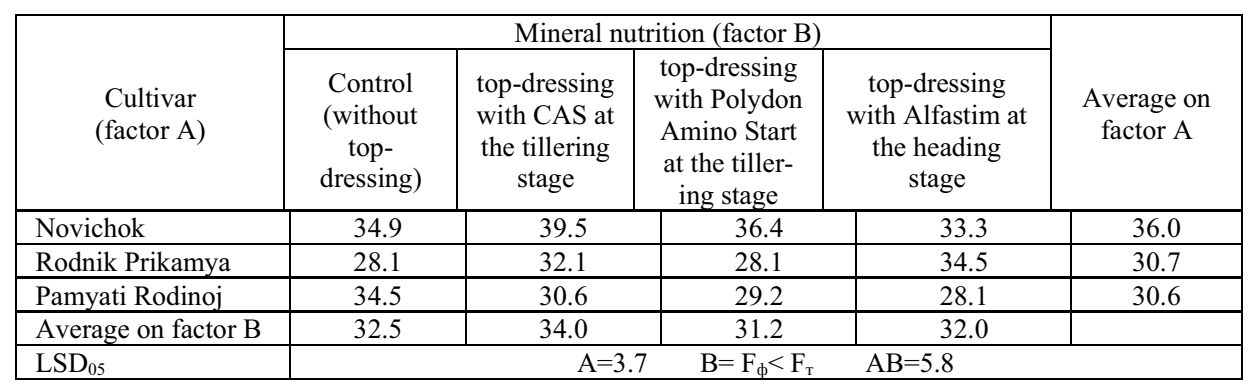

\section{Conclusions}

As a result of the studies, the effectiveness of using top-dressing with liquid mineral fertilizer CAS, organic-mineral fertilizer Amino Start and growth stimulator Alfastim was revealed on barley. Cultivar-specificity in the reaction of cultivars to the applied elements of technology was noted.

The use of all studied top-dressings contributed to an increase in the yield of barley grains of the cv. Novichok. The cv. Pamyati Rodinoj responded positively to the application of CAS and Amino Start at the barley tillering stage. The increase in yield of the cv. Rodnik Prikamya (0.34 t/ha) was noted only when using CAS in the tillering stage.

The studied cultivars responded differently to the use of top-dressing preparations. So, in the cv. Novichok, an increase in the volume weight and 1000-grain mass was noted for all the studied variants. In the cv. Pamyati Rodinoj, the application of CAS and Alfastim influenced the increase in the grain volume weight, and the 1000 -grain mass. The influence of the studied preparations on the volume weight and 1000-grain mass of the cv. Rodnik Prikamya did not reveal.

The amount of protein in the grain in the variants with increased productivity remains stable compared to the control or slightly improves, indicating an improvement in the nutrition of the plants and its balance as a result of top-dressing application of the preparations in the test variants. Of the studied cultivars, the greatest grain protein content was distinguished by the cv, Pamyati Rodinoj - 114.6-131.1 g/ $/ \mathrm{kg}$ of grain. The use of Amino Start in the tillering stage on this cultivar increased the protein content by 15.0-16.5 $\mathrm{g} / \mathrm{kg}$. In the cv. Novichok, when applying the growth stimulant Alfastim at the heading stage, an increase in protein content by $4.0-4.8 \mathrm{~g} / \mathrm{kg}$ was noted. The use of studied topdressing preparations on barley cv. Rodnik Prikamya did not have a reliable effect on this indicator. 


\section{References}

1. D.S. Grib, L.S. Kanonuchenko, Collection of scientific articles of researchers and postgraduates of Belarus Research Institute of Crop Farmeng and Fodders, 156 (2002)

2. V.M. Shevtsov, N.G. Malyuga, Krasnodar, Kuban' State Agricultural University, 138 (2008)

3. M.M. Nafikov, A.A. Zamaydinov, V.N. Fomin, S.I. Spichkov, Fodder production, 4, $11(2013)$

4. V.N. Fomin, S.I. Spichkov, M.M. Nafikov, A.A. Zamaidinov, Fodder production, 5, 32 (2014)

5. V.Yu. Grebenshchikov, V.V. Verkhoturov, S.L. Belopukhov, I.I. Seregina, Problems of Agrochemistry and Ecology, 3, 20 (2019)

6. A. Mutlu, Fresenius Environ Bull., 29(12), 10840 (2021)

7. B.P. Baker, B.M. Meints, P.M. Hayes, Organic Agriculture, 10, 35 (2020)

8. L.M. Kozlova, E.N. Noskova, F.A. Popov. Theor. Appl. Ecol., 3, 147 (2020)

9. O. Aksenov, T. Gorlovich, O.V. Mel'nikova, Materials of IX International scientific conference, 232 (2012)

10. T.A. Aseeva, S.A. Shukyurov, Achievements of Science and Technology of AIC, 14 (2010)

11. V.V. Glukhovtsev, N.V. Sanina, A.A. Apalikov, Izvestia Orenburg State Agrarian University, 6(56), 20 (2015)

12. A.A. Zavalin, L.S. Chernova, A.Yu. Gavrilova, Plodorodie, 6, 41 (2013)

13. M.S. Izydorczyk, Can. J. Plant Sci., 94, 573 (2014) 